\title{
Community Participation-Based Smart City Development
}

\author{
Eko Eddya Supriyanto ${ }^{1}$, Jumadil Saputra ${ }^{2}$, Meida Rachmawati $^{3}$, Fibry Jati Nugroho ${ }^{4}$ \\ \{ekoeddya@students.undip.ac.id ${ }^{1}$, jumadil.saputra@umt.edu.my ${ }^{2}$ \} \\ Program Doctor of Public Administration, Universitas Diponegoro \& STKIP NU Tegal ${ }^{1}$, \\ Faculty of Business, Economic and Social Development, University Malaysia Trengganu ${ }^{2}$, \\ Universitas Ngudi Waluyo, Semarang $^{3}$, Sekolah Tinggi Teologi Sangkakala, Salatiga ${ }^{4}$
}

\begin{abstract}
Community participation is essential in development. This article aims to build an integrative, intelligent city concept in public services based on community participation. The method used in writing this paper is a qualitative method with a systematic literature review approach. The theoretical basis used in this study is the theory of smart cities, e-government, community participation as factors that make the innovative city concept based on the involvement of intelligent people. This research concludes that the contribution of thoughtful community participation will encourage the development of smart cities closer to the community's wishes so that the services provided by the government can be easily implemented.
\end{abstract}

Keywords: Smart City; Community Participation; Public Service

\section{Introduction}

The outbreak of the Covid-19 pandemic has accelerated digital transformation, digital city planning and the pace of implementing shortcut cities in governance in Indonesia [1]. Even as a result of the pandemic, the implementation of smart cities has accelerated in Southeast Asia. The central government has launched an electronic-based government system by strengthening the digital government roadmap, which will begin in 2022 [2]. Of course, this is a breath of fresh air for the digitalization journey in governance to continue to study how far access to disruption can increase the participation of the Indonesian people [3].

The internet network infrastructure that is still not evenly distributed throughout the country is certainly a separate obstacle for developing smart cities [4]. But even so, in Indonesia, quite a few have implemented the innovative city model, massive cities such as DKI Jakarta, Bandung, Semarang, Yogyakarta, Surabaya, Makassar, Medan, Padang, Banyuwangi and other cities [5]. An intelligent city itself does not have to be in the form of a town. Still, it can be reduced a little, as done by several property developers in Indonesia who have developed small cities that can be turned into smart cities [6].

The initial idea of a smart city is to improve the city's quality to be innovative through improving technology infrastructure, especially Information Communication and Technology in its area, by developing software and collaborating with the private sector. However, now the development of the smart city concept has also experienced a relatively rapid increase, both in 
terms of publications and applications, especially since the European Union in 2010 created a smart city project that aims to develop intelligent solutions to the challenges of urbanisation, globalisation, and climate change. Several other reasons that also support the development of smart cities, among others, are the widespread use of technological devices such as mobile phones (mobile devices) and the internet among the community, the urban dimension that continues to grow higher, and the need to protect the environment from pollution and energy consumption [7].

One of the most prominent discussions in the smart city concept is a discussion that focuses on the development of computer technology and information communication technology [8]. Whereas its meaning is not only limited to that, but has also expanded to various fields such as in the social, environmental, business and management areas, energy, and so on. There are two main groups of concepts contained in a smart city, namely: (1) the concept of a smart city that is oriented towards technology and ICT or complex infrastructure (hard infrastructure) or also called hardware, and (2) the concept of a smart city that focuses on society, inclusion. And participation or referred to as soft infrastructure and sometimes also referred to as software. Of these two groups, the smart city concept that focuses on complex infrastructure still dominates. There can be seen from more than two thousand publications on intelligent cities based on Scopus data, more than 50 per cent of the discussions are in the field of computer science and technology, while the rest discuss the concept of smart cities from various other areas of science, such as social, environmental, and so on [9].

One of the previous studies discussing and linking the importance of the innovative city concept and participation is that there are three groups of intelligent city concept development towards participatory, namely: smart city 1.0, smart city 2.0 , and smart city 3.0 . The brilliant city 1.0 group uses a maximum advanced technology approach, and technology is considered an essential role in the survival, sustainability, and control of a town. The smart city 2.0 group began to use technology very carefully, only to solve specific problems. In addition, in this group, the role of city residents has already started to be involved in selecting the technology used and in making decisions. However, citizen participation is considered only a formality, and the number of participants is still minimal. The smart city 3.0 group is formed when the participation and involvement of city residents have begun to increase and the creation of collaborative activities and actions with a broader goal, namely to grow social inclusion, improve democracy, and develop social capital in the community [10].

The journey of the innovative city concept from time to time illustrates that the need for community involvement and participation is to realise a better smart city. A smart city in the future will be a concept that provides the most excellent opportunity for people to be aware of the problems they face and the potential they have. People can enter the process of determining policies, solving city problems, city solutions, etc. and improving city services. From the explanation above, it can be seen that the current development of intelligent cities tends to lead to a more focused approach to software in general and the importance of community participation in particular. In addition to aiming to increase social inclusion, improve democracy, and develop social capital in the community, participation is also needed as an effort to create a smart city that follows the character and needs of citizens, serving urban problems through participation or citizen complaints, and fulfilling community rights in the development process. 


\section{Methodology}

The analysis and discussion were carried out based on a literature study and a systematic literature review methodology [11]. This methodology is carried out by summarising the results of previous studies that present more comprehensive and balanced facts [12]. Synthesis of derivatives is carried out using narrative techniques or qualitative techniques. A qualitative approach in the systematic literature review methodology is used to synthesise the results of previous research, which are descriptive qualitative. This method of summarising the results of qualitative research is called meta-synthesis, which is a technique for integrating data to obtain new theories and concepts in a deeper and more comprehensive level of understanding.

Data collection in the systematic literature review methodology was carried out through searching ScienceDirect, web of science (WoS) and the latest published research results. In the meta-aggregation approach, research topics are elaborated into specific themes to produce a conceptual framework. Then, within particular themes, relevant research articles are searched and compared and summarised between one another. In this meta-aggregation approach, the synthesis results are "aggregates" of various research results according to the relevant themes. The synthesis process in this approach will go through several steps, namely: (1) the themes and concepts from the relevant studies are extracted, (2) the results of this extraction are organised into significant findings (main/primary); (3) the findings are grouped into categories; (4) the categories are then synthesised into themes (adjusted according to the conceptual framework that is prepared).

\section{Results and Discussion}

\subsection{The Basic Concept of a Smart City}

The approach in the smart city concept can be divided into two main groups, namely: (1) the smart city concept, which is oriented and focused on information and communication technology or complex infrastructure, one of the main goals of which is to improve the quality of life and decrease the quality of life. Environment and contrary to this, a group of other researchers also debated the importance of (2) the concept of a smart city that is oriented and focused on society, inclusion, and participation or also known as soft infrastructure to improve the quality of life and environment, develop intelligence, improve welfare, effectiveness, and competitiveness.

Of the two approaches, the approach oriented towards complex infrastructure and ICT is more dominant than the approach introduced to soft infrastructure. There can be seen from the number of publications on intelligent cities, which have increased significantly in various related fields. From more than 2000 publications, most of the research has been carried outcomes from computer science and technology (computer science and engineering), followed by research in social science, mathematics, and several other fields. Therefore, discussions in the field of social science in the context of smart cities must be encouraged and increased in number and expanded in the area of debate. This is because understanding the concept of a smart city is limited to the use of ICT, big data, the Internet of Things and various modern technologies but has now expanded to multiple fields, one of the most important of which is deepening in the field of social science.

To realise and increase community participation, it can be concluded that the approach to soft infrastructure must take precedence before going to the complex infrastructure approach. A 
city can become "smart" when the investment developed in the city is focused on modern transportation and ICT and aspects of human capital and social capital to create sustainable economic growth and quality-high standard of living, with good management of natural resources through participatory governance.

\subsection{Smart City Based on Community Participation}

The smart city concept model consists of three main dimensions, namely technology, people, and institutions. An intelligent city towards participatory is realised through one of its dimensions, namely institutions. Institutions are governance to increase the role of institutions, participation, and community involvement. This dimension consists of supporting elements such as government, policies, and regulations. However, in realizing a participatory smart city, just encouraging institutional factors is not enough. The combination of these three dimensions must be utilised to create community participation as expected. Institutional factors alone will not run independently if they are not supported and strengthened by other factors, namely humans and technology. In particular, the concept that describes the strengthening of institutional factors is innovative community.

Governments in developed countries have moved towards a democratic and participatory model of government. The public is given the freedom and space to enter into the process and determination of government policies. Participatory governance provides opportunities for people to be aware of the problems they face and their potential. So that later development is expected to touch the community more, the action becomes more effective and efficient in the use of its resources, the community is more responsible for the development and utilisation of development results, the community can learn through the development process, create solidarity in the community, and form the characteristics of an independent society. And able to decide things that affect their future.

The word participation comes from pars and capere. Pars means part, while capere means to take. Participation is adapted from the English language, namely participation, which means taking part or participating. The ideas in participatory pay more attention to the inclusion of broader rights such as the relationship between the state and society and providing opportunities for the community to make decisions. The development will be more successful if the community has and creates a commitment to participate as development actors and is supported by community members who can be used as role models, directors, mentors and motivators. Therefore, citizen participation is very much needed because they are the implementers of various existing development activities. To create community participation, it is vital to carry out several things such as it can benefit the community; the community can understand the meaning; carried out according to the context and purpose, carried out honestly, openly, and can be accounted for, and indeed must involve the community in its implementation.

Community participation can be above conventional democratic institutional forms at the level of practical goals, such as improving government responsiveness and effectiveness. In addition, community participation can create conditions and situations that are better, fairer, more involved, considerate and responsible. There are three dimensions of direct participation, which are essential factors in the participatory governance model. Participating parties, which can be done openly for community members who want to be involved, while other processes can also include representing interested parties; 2) participation that creates a result or decision, rather than just building communication; generally, participants are only listeners and do not take part in making certain decisions; 3) there is a relationship between discussion, public activity, and policy (policy). 
The participatory typology was developed to understand the differences between existing interpretations, approaches, and methods in the most prioritised contexts. The division of this typology can be a reference in choosing the appropriate method for the type of participation needed and categorises the kind of participation. For example, the participation ladder typology by Arnstein [13] and the participation wheel typology by Davidson [14]; 2) typology based on the nature of the involvement following the direction of the flow of communication. Examples are as written in public participation methods: a framework for evaluation in science; 3) typology based on a theoretical basis that distinguishes between normative and pragmatic participation. For example, the participation made by Beierle [15]; 4) typology based on goals for involvement that has been done.

A smart city is expected to increase public participation in utilising applications to provide input and criticism quickly to the government. In Indonesia, several programs designed to increase community participation have not run effectively. This could be due to several reasons, but mainly due to a lack of socialisation in the community. A smart city is expected to increase public participation in utilising applications to provide input and criticism quickly to the government. In Indonesia, several programs designed to increase community participation have not run effectively. This could be due to several reasons, but mainly due to a lack of socialisation in the community.

Big cities, such as Jakarta, Bandung, Tangerang, Malang, and Surabaya, have carried out thee-Musrenbang program or electronic development planning deliberation. Musrenbang is a forum for gathering actors interested in the preparation of national and regional development plans. From this forum, development planning documents will be produced, both long-term, medium-term, and short-term development plans implemented by state administrators and the community elements. E-musrenbang was created as an ICT-based planning innovation to receive the most comprehensive community participation in accepting various development proposals [16]. The city of Surabaya has started using e-musrenbang in 2010, but the participation that has taken place in the thee-musrenbang process is still far from expectations. The ability to capture aspirations and representation in access to e-musrenbang is not enough to guarantee that the aspirations of the lower classes can arrive and become part of the decision making at the next stage. In seeking aspirations, the opportunity to express aspirations has not been entirely given to the public. Aspirations or proposals are only given to a few parties, the elite at the RW or Kelurahan level.

In this case, the strength of the intelligent community concept needs to be taken into account; groups that can provide aspirations are expected to become community representatives in representing and representing their groups so that they can convey aspirations in a supportive atmosphere. By strengthening the concept of an intelligent community, it is inevitable that the community's voice from the lowest level can be presented and can later influence policies in the city development process.

\section{Conclusion}

Based on the discussion above, it can be concluded that community participation in the context of a smart city is a voluntary contribution from the community to the government in the development process, service improvement, disaster preparedness, and administration. This participation can be delivered through facilities provided by the government, either through the ICT system or not. The convenience of ICT is not the only way that is encouraged to convey aspirations and contributions. The government must continue to attract the public through 
various methods, both conventional and traditional. The effectiveness of community involvement depends on their willingness to participate, and the community must also believe that their participation will positively impact their community.

Based on the typology of participation, the participatory government model based on the smart city concept is more likely to be in a typological model that leads to (1) typology based on the nature of participation, which as per the direction of the flow of communication, as in public participation methods: a framework for evaluation in science ( Rowe \& Frewer, 2000), and (2) a typology of participation based on a theoretical basis which distinguishes between normative participation and pragmatic participation. For example, the participation made by Beierle (2002). In its characteristics, participation based on the smart city concept is in the aspects of passive participation, informative participation, and interactive participation, which provide a role in the activity planning analysis process.

\section{References}

[1] E. E. Supriyanto, I. S. Bakti, and M. Furqon, "THE ROLE OF BIG DATA IN THE IMPLEMENTATION OF DISTANCE," Paedagoria J. Kajian, Penelit. dan Pengemb. Pendidik., vol. 6356, no. 4, pp. 61-68, 2021, doi: 10.31764.

[2] A. Ibrahim, A. Arief, and S. Do Abdullah, "Keamanan Untuk Penerapan Layanan Publik Pada Sistem Pemerintahan Berbasis Elektronik (SPBE): Sebuah Kajian Pustaka Sistematis," IJIS - Indones. J. Inf. Syst., vol. 5, no. 2, pp. 135-143, 2020, doi: 10.36549/ijis.v5i2.105.

[3] B. Aragona and R. De Rosa, "Big data in policy making," Math. Popul. Stud., vol. 26, no. 2, pp. 107-113, 2019, doi: 10.1080/08898480.2017.1418113.

[4] D. Y. Tadeus, Yuniarto, and F. Mangkusasmito, "LoRa Gateway as Internet of Things (IoT) Infrastructure Components on Undip Vocational School," IOP Conf. Ser. Mater. Sci. Eng., vol. 771, no. 1, 2020, doi: 10.1088/1757-899X/771/1/012009.

[5] Y. Arafah and H. Winarso, "Peningkatan dan Penguatan Partisipasi Masyarakat dalam Konteks Smart City," Tataloka, vol. 22, no. 1, pp. 27-40, 2020, doi: 10.14710/tataloka.22.1.27-40.

[6] J. Chambers and J. Evans, "Informal urbanism and the Internet of Things: Reliability, trust and the reconfiguration of infrastructure," Urban Stud., vol. 57, no. 14, pp. 29182935, 2020, doi: 10.1177/0042098019890798.

[7] T. S. Wibowo, Endroyono, and I. Pratomo, "Analysis of Malang City Readiness in Realizing Smart Tourism with New Integrated E-Readiness Model," Proceeding ICoSTA 20202020 Int. Conf. Smart Technol. Appl. Empower. Ind. IoT by Implement. Green Technol. Sustain. Dev., 2020, doi: 10.1109/ICoSTA48221.2020.1570616406.

[8] S. Flensburg and S. S. Lai, "Networks of power. Analysing the evolution of the Danish internet infrastructure," Internet Hist., vol. 5, no. 2, pp. 79-100, 2021, doi: 10.1080/24701475.2020.1759010.

[9] Y. Wu, Y. Wu, J. M. Guerrero, and J. C. Vasquez, "Digitalization and decentralization driving transactive energy Internet: Key technologies and infrastructures," Int. J. Electr. Power Energy Syst., vol. 126, no. PA, p. 106593, 2021, doi: 10.1016/j.ijepes.2020.106593.

[10] Y. Pi, "Machine learning in governments: Benefits, challenges and future directions," eJournal eDemocracy Open Gov., vol. 13, no. 1, pp. 203-219, 2021, doi: 10.29379/jedem.v13i1.625. 
[11] S. Houghton-Jan, A. Etches-Johnson, and A. Schmidt, "The read/write web and the future of library research," J. Libr. Adm., vol. 49, no. 4, pp. 365-382, 2009, doi: 10.1080/01930820902832496.

[12] W. M. K. Trochim, Research Methods. 2019.

[13] S. R. Arnstein, “A ladder of citizen participation,” J. Am. Inst. Plann., vol. 35, no. 4, pp. 216-224, 1969.

[14] W. B. Davidson and P. R. Cotte, "Sense of community and political participation," J. Community Psychol., vol. 17, no. 2, pp. 119-125, 1989.

[15] T. Beierle, Public Participation in Environmental Decisions: An Evaluation Framework Using Social Goals. 1998.

[16] N. S. Yunas, "Implementasi e-Government dalam Meminimalisasi Praktik Rent Seeking Behaviour pada Birokrasi Pemerintah Kota Surabaya," Matra Pembaruan, vol. 4, no. 1, pp. 13-23, 2020, doi: 10.21787/mp.4.1.2020.13-23. 